RASĀYAN J. Chem.

Vol. 13 | No. 4 |2370-2375| October - December | 2020 ISSN: 0974-1496 | e-ISSN: 0976-0083 | CODEN: RJCABP

\title{
CATALYTIC CRACKING OF VACUUM DISTILLATES ON COMPOSITE CATALYSTS
}

\author{
R. Kh. Ibrasheva ${ }^{1}$, V.S.Yemelyanova ${ }^{1}$, L.R. Sassykova ${ }^{2, *}$, U. N. \\ Dzhatkambayeva $^{1}$, T.V. Shakiyeva ${ }^{1}$, B.T. Dossumova ${ }^{1}$, N.K. Zhakirova ${ }^{2}$, \\ S.Sendilvelan ${ }^{3}$ and T. M. Seilkhanov ${ }^{4}$ \\ ${ }^{1}$ Scientific and Production Technical Center "Zhalyn" LLP, 172, Bogenbai Batyr Str., \\ Almaty-050012, Kazakhstan \\ ${ }^{2}$ Al-Farabi Kazakh National University, 71, al-Farabi Ave., Almaty-050040, Kazakhstan \\ ${ }^{3}$ Department of Mechanical Engineering, Dr.M.G.R. Educational and Research Institute, \\ University, Chennai-600095, Tamilnadu, India \\ ${ }^{4}$ Sh. Ualikhanov Kokshetau State University, 76, Abay Str., Kokshetau-020000, Kazakhstan \\ *E-mail: larissa.rav@mail.ru
}

\begin{abstract}
The article describes the study of the regularities of oxidative cracking of vacuum gas oils of Atyrau and Zhetybay oil on composite catalysts based on natural zeolite Taizhuzgen and Narynkol clay. During oxidative cracking on synthesized zeolite-containing catalysts, an increase in gas and coke formation is observed in comparison with cracking in an inert atmosphere. These data indicate a magnification in the catalytic destruction of high molecular weight hydrocarbons in the presence of traces of air. The influence of the fractional composition of the processed feedstock on the laws of the catalytic process was determined; the dependence of the composition and yield of cracking products on the ratio of components in the catalyst was established. When varying the concentration of air in the reaction mixture, a maximum concentration of the kerosene-gas oil fraction in the cracked products is observed, corresponding to the air supply at a speed of $0.15 \mathrm{~h}^{-1}$. The influence of air on the course of the cracking reaction and the relationship between the parameters of oxidative-catalytic cracking were determined. The oxidative cracking of high molecular weight hydrocarbons on composites of natural zeolite and clay proceeds by a radical mechanism. The data confirm that the process of oxidative cracking in the gas phase is an environmentally safe and effective way to obtain cracking products of heavy raw materials.
\end{abstract}

Keywords: Catalytic Cracking, Vacuum Distillates, Natural Taizhuzgen Zeolite, Narynkol Clay, Atyrau Oil, Zhetybay Oil.

(c) RASĀYAN. All rights reserved

\section{INTRODUCTION}

The main trend in the development of the global oil refining industry is the introduction of new technologies that allow the maximum use of hydrocarbon raw materials for obtaining high-quality target products. ${ }^{1-5}$ In recent years, there has been a tendency to increase the use of vacuum gas oil, fuel oil and tar as raw material. The shortage of proven reserves and production of light oils observed in the last decades has led to the intensification of research and the search for new approaches to the processing of residual high-boiling fractions. The solution to the problem is of particular importance for Kazakhstan due to the high content of heavy hydrocarbons in domestic oil. ${ }^{6-9}$ Oil refining depth at Kazakhstan oil refineries varies due to different technological support of secondary processes. The content of fuel oil in heavy oils can reach half and more, and a significant part of it is used for the production of boiler fuel or raw materials for the production of bitumen and coke, which is the main reserve for oil deepening. The creation of scientifically based methods for preparing composite systems from Kazakhstan's mineral raw materials active in the catalytic cracking of oil residues and new technological solutions to this process will contribute to import substitution and a sharp reduction in costs in modernized production facilities. An analysis of the literature data shows that the most promising method for producing light hydrocarbon

Rasayan J. Chem., 13(4), 2370-2375(2020)

http://dx.doi.org/10.31788/ RJC.2020.1345948

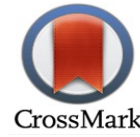


RASĀYAN J. Chem.

Vol. 13 | No. 4 |2370-2375| October - December | 2020

fractions is the catalytic cracking of oil residues in an oxidizing medium, i.e. in the presence of air additives in the reaction medium. ${ }^{10-18}$ The creation of new catalytic systems for this process based on composites from natural raw materials is the most optimistic way to increase the economic efficiency of the developed technology.

This work aimed to study the patterns of oxidative cracking of vacuum gas oils on composite catalysts based on natural Taizhuzgen zeolite and Narynkol clay.

\section{EXPERIMENTAL}

Zeolite-containing composite catalysts were prepared from natural Taizhuzgen zeolite and Narynkol clay. The initial zeolite and clay were crushed and sieved with a selection of fractions of 63-80 microns. The zeolite was activated by the ion exchange of sodium cations of the zeolite framework to cations of lanthanum and ammonium. ${ }^{19-22}$ The chemical composition of activated zeolite and clay, as well as zeolitecontaining composites, was determined by the X-ray fluorescence method. The concentration of lanthanum in the catalysts was measured on a DFS-13 spectrograph using calibration graphs constructed using a reference sample.

The phase composition of zeolite-containing composites was determined by the X-ray spectral method. The measurement was carried out on a DRON-4 X-ray diffractometer equipped with an Iskra-330 control microcomputer. The value of the specific surface of the catalysts was determined by the method of thermal desorption, which allows surface measurements in the range of $0.1-500 \mathrm{~m}^{2} / \mathrm{g}$. The individual hydrocarbon composition of kerosene-gas oil fractions was determined using HP 5890/5972 gas chromatography-mass spectrometer. ${ }^{23-25}$

Vacuum distillates obtained by distillation under reduced pressure of the Zhetybay and Atyrau oils were subjected to catalytic cracking. During the process, a continuous supply of air to the central zone of the flow reactor through the inlet pipe simultaneously with the supply of a mixture of the catalyst with the raw material being subjected to cracking is carried out. The distillation apparatus was evacuated by the VN-4 pump, the residual pressure in the system was $5.10^{-2} \mathrm{~mm} \mathrm{Hg}$ and was monitored by a vacuum gauge using a PMT-2 indicator lamp. A fraction was selected whose boiling range was $110-220^{\circ} \mathrm{C}$, which corresponds to a boiling point of $350-500^{\circ} \mathrm{C}$ at normal pressure. The content of each fraction was determined by the gravimetric method and was expressed in mass percent. The sulfur content in fuel oils and vacuum gas oils was determined by high-temperature oxidation of samples followed by acid-base titration of the resulting sulfur dioxide. ${ }^{26-28}$

Sample spectra of oils were recorded on Jeol (Japan) JNN-ECA 400 spectrometer. The operating frequency of the spectrometer is $400 \mathrm{MHz}$ and $100 \mathrm{MHz}$ for ${ }^{1} \mathrm{H}$ and ${ }^{13} \mathrm{C}$ cores, respectively. ${ }^{29-31} \mathrm{The}$ examination was carried out at room temperature with $\mathrm{CDCl}_{3}$ solvent. Chemical shifts are determined relative to signals of residual protons or carbon atoms of deuterated chloroform.

\section{RESULTS AND DISCUSSION}

In Table-1 data on the chemical composition of catalysts made of Taizhuzgen zeolite and Narynkol clay are presented.

Zeolite-containing catalysts with a unique microporous structure and acid-base properties are known to catalyze the conversion reactions of $\mathrm{C}_{2}-\mathrm{C}_{7}$ paraffin hydrocarbons, turning them into valuable products of organic synthesis. ${ }^{8-17}$

The regularities of the cracking process of heavy oil fractions in inert and oxidizing media were studied on the example of vacuum distillates of Atyrau and Zhetybay oil. To determine the fragment component of the studied oil by NMR, the techniques proposed in refs ${ }^{29,30}$ were applied (Table-2,Table-3, and Fig.-1).

Table-1: Catalysts made of Taizhuzgen Zeolite and Narynkol Clay

\begin{tabular}{c|c|c|c|c}
\hline $\begin{array}{c}\text { Chemical } \\
\text { Composition }\end{array}$ & Narynkol Clay & $\begin{array}{c}14 \% \text { Zeolite- } \\
\text { Containing } \\
\text { Composite }\end{array}$ & $\begin{array}{c}20 \% \text { Zeolite- } \\
\text { containing } \\
\text { Composite }\end{array}$ & $\begin{array}{c}\text { Taizhuzgen } \\
\text { Zeolite }\end{array}$ \\
\hline $\mathrm{SiO}_{2}$ & 38.05 & 40.00 & 47.07 & 67.93 \\
\hline $\mathrm{CaO}$ & 20.40 & 19.77 & 15.14 & 1.97 \\
\hline
\end{tabular}


RASĀYAN J. Chem.

Vol. 13 | No. 4 |2370-2375| October - December | 2020

\begin{tabular}{c|c|c|c|c}
\hline $\mathrm{Al}_{2} \mathrm{O}_{3}$ & 8.49 & 9.97 & 11.51 & 14.28 \\
\hline $\mathrm{MgO}$ & 6.15 & 6.27 & 4.72 & 1.39 \\
\hline $\mathrm{Fe}_{2} \mathrm{O}_{3}$ & 4.07 & 3.75 & 4.01 & 1.79 \\
\hline $\mathrm{K}_{2} \mathrm{O}$ & 1.80 & 2.29 & 3.02 & 4.47 \\
\hline $\mathrm{Na}_{2} \mathrm{O}$ & 1.10 & $<0.50$ & 0.55 & 1.11 \\
\hline $\mathrm{TiO}_{2}$ & 0.44 & 0.23 & 0.41 & 0.29 \\
\hline $\mathrm{P}_{2} \mathrm{O}_{5}$ & 0.11 & 0.15 & 0.14 & 0.01 \\
\hline $\mathrm{MnO}$ & 0.10 & 0.15 & 0.11 & 0.04 \\
\hline Calcination losses & 19.47 & 17.43 & 13.52 & 7.04 \\
\hline $\mathrm{La}$ & 0 & 0.20 & 0.20 & 0.24 \\
\hline \multicolumn{7}{|r}{}
\end{tabular}

Table-2: Numerical Values of Chemical Shifts ${ }^{13} \mathrm{C}$ NMR of Petroleum Products ${ }^{29-31}$

\begin{tabular}{c|c|l}
\hline$\delta\left({ }^{13} \mathrm{C}\right), \mathrm{ppm}$ & $\begin{array}{c}\text { Atom } \\
\text { Designation }\end{array}$ & \multicolumn{1}{c}{ The Functional Group of Atoms } \\
\hline $7-17$ & $\mathrm{C}_{\mathrm{p} . \mathrm{n}}$ & Primary carbon atoms in the methylene group \\
\hline $17-25$ & $\mathrm{C}_{\mathrm{pa}}$ & Primary carbon atoms bonded to CH group or aromatic nucleus \\
\hline $17-50$ & $\mathrm{C}_{\mathrm{s}+\mathrm{q}}$ & Secondary and quaternary $\mathrm{C}$ atoms of saturated compounds \\
\hline $25-65$ & $\mathrm{C}_{\mathrm{al}}$ & Aliphatic CH groups \\
\hline $25-50$ & $\mathrm{C}_{\mathrm{q}}$ & Quaternary carbon atoms of saturated compounds \\
\hline $108-118$ & $\mathrm{C}_{\mathrm{ol}}$ & Olefin fragments \\
\hline $110-135$ & $\mathrm{C}_{\mathrm{at}}$ & Tertiary C atoms of aromatic systems \\
\hline $130-137$ & $\mathrm{C}_{\mathrm{msca}}$ & Methyl-substituted aromatic carbon atoms \\
\hline $137-148$ & $\mathrm{C}_{\mathrm{alk}}$ & Alkyl and naphthyl substituted carbon atoms of aromatic nuclei \\
\hline $148-170$ & $\mathrm{C}_{\mathrm{arp}}$ & $\begin{array}{l}\text { Aromatic carbon atoms substituted with a phenolic or ether } \\
\text { group }\end{array}$ \\
\hline $170-200$ & $\mathrm{C}_{\mathrm{c}}$ & Carbonyl carbon atoms \\
\hline
\end{tabular}

Table-3: Fragment Composition of Kazakhstan Oils Investigated, wt. \%

\begin{tabular}{c|c|c}
\hline Type of Atoms & Atyrau Oil & Zhetybay Oil \\
\hline $\mathrm{H}_{\mathrm{arp}}$ & 0.98 & 0.94 \\
\hline $\mathrm{H}_{\mathrm{ol}}$ & 0 & 33.49 \\
\hline $\mathrm{H}_{\mathrm{al}}$ & 99.02 & 65.57 \\
\hline $\mathrm{H}_{\alpha}$ & 5.88 & - \\
\hline $\mathrm{H}_{\beta}$ & 82.35 & 40.57 \\
\hline $\mathrm{H}_{\gamma}$ & 10.79 & 20.28 \\
\hline $\mathrm{C}_{\mathrm{arp}}$ & 3.52 & 2.51 \\
\hline $\mathrm{C}_{\mathrm{al}}$ & 96.48 & 97.49 \\
\hline
\end{tabular}

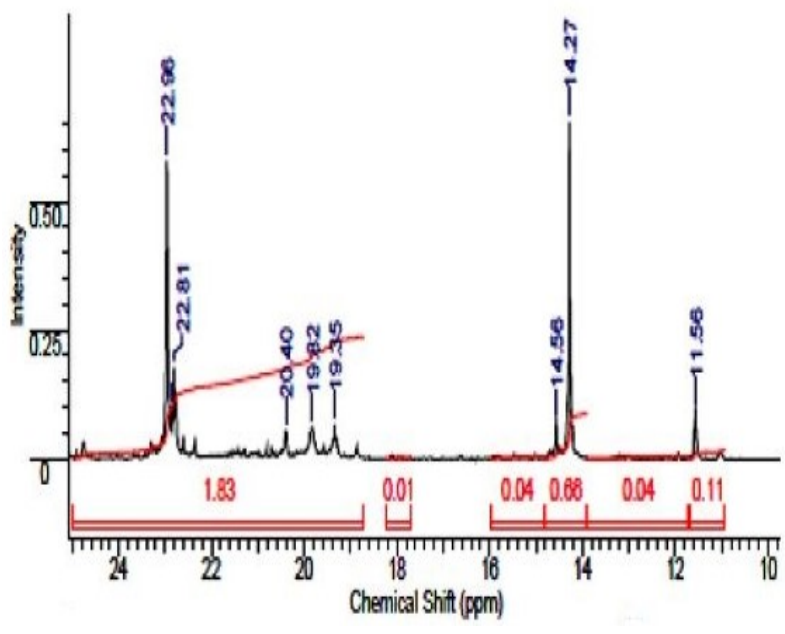

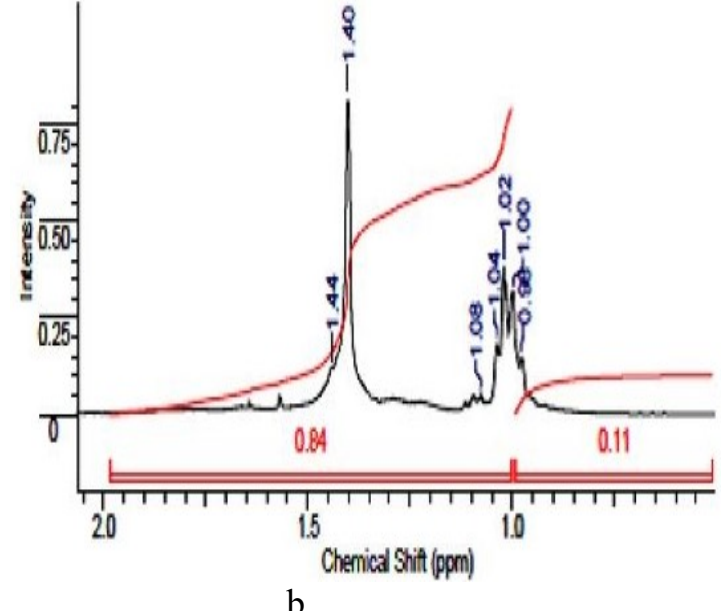

b

Fig.-1: Integrated Sections of ${ }^{13} \mathrm{C}$ NMR Oil Spectra of the Oils: (a) Atyrau, (b)Zhetybay 
RASĀYAN J. Chem.

Vol. 13 | No. 4 |2370-2375| October - December | 2020

The Atyrau and Zhetybay oils are close in sulfur content, but the distribution of sulfur by fractions for them is different (Table-4). In the case of Zhetybay oil, sulfur-containing compounds are more concentrated in the heavy fraction - vacuum gas oil. Therefore, the sulfur concentration in the kerosenegas oil fraction of the Atyrau oil is higher than for the Zhetybay oil.

Table-4: Fractional Composition and Concentration of Sulfur in the Oils Studied and their Fractions

\begin{tabular}{c|c|c|c|c}
\hline \multirow{2}{*}{$\begin{array}{c}\text { Fractional } \\
\text { Composition }\end{array}$} & \multicolumn{2}{|c|}{ Atyrau Oil, wt. \% } & \multicolumn{2}{c}{ Zhetybay Oil, wt. \% } \\
\cline { 2 - 5 } & $\begin{array}{c}\text { Hydrocarbon } \\
\text { Fractions }\end{array}$ & Sulfur & $\begin{array}{c}\text { Hydrocarbon } \\
\text { Fractions }\end{array}$ & Sulfur \\
\hline Original Oil & 100.0 & 0.9 & 100.0 & 1.0 \\
\hline Petrol & 0.6 & - & 3.5 & - \\
\hline Light Gas Oil & 56.5 & 0.5 & 34.4 & 0.2 \\
\hline Vacuum Gas Oil & 17.5 & 1.1 & 21.3 & - \\
\hline Heavy Residue & 25.4 & - & 40.8 & 1.5 \\
\hline
\end{tabular}

The effect of the ratio of activated Taizuzgen zeolite and Narynkol clay on the yield of vacuum gas oil cracking products from Zhetybay oil in an inert atmosphere and the presence of air is shown in the Table5 .

Table-5: Cracking of a Vacuum Distillate of Zhetybay Oil in $0.2 \%$ Suspensions of Zeolite-containing Composites

\begin{tabular}{|c|c|c|c|c|c|c|c|c|}
\hline \multirow{2}{*}{$\begin{array}{l}\text { Experience } \\
\text { Conditions }\end{array}$} & \multirow{2}{*}{$\begin{array}{c}\text { The Zeolite Content } \\
\text { in the Composite, } \\
\text { wt. } \%\end{array}$} & \multicolumn{6}{|c|}{ The Yield of Cracking Products, wt. \% } & \multirow[t]{2}{*}{ Total } \\
\hline & & Gas & Gasoline & $\begin{array}{c}\text { Light } \\
\text { Gas Oil }\end{array}$ & $\begin{array}{c}\text { Heavy } \\
\text { Residual }\end{array}$ & Coke & Losses & \\
\hline \multirow[t]{5}{*}{$\begin{array}{c}\text { Inert } \\
\text { Atmosphere }\end{array}$} & $\begin{array}{c}0 \\
\text { (Clay not activated) }\end{array}$ & 22.8 & 11.2 & 15.6 & 47.0 & 1.0 & 2.4 & 100.0 \\
\hline & 0 (Activated Clay) & 27.6 & 13.3 & 16.5 & 41.7 & 0.7 & 0.2 & 100.0 \\
\hline & 14.0 & 19.3 & 10.6 & 16.1 & 53.4 & 0.6 & 0 & 100.0 \\
\hline & 20.0 & 27.0 & 7.8 & 15.8 & 49.0 & 0.4 & 0 & 100.0 \\
\hline & 50.0 & 15.6 & 6.3 & 16.4 & 61.2 & 0.5 & 0 & 100.0 \\
\hline \multirow[t]{5}{*}{$\mathrm{W}_{\text {air }}=0.05 \mathrm{~h}^{-1}$} & 0 (Clay Activated) & 17.1 & 11.3 & 14.5 & 55.3 & 1.8 & 0 & 100.0 \\
\hline & 14.0 & 41.2 & 18.0 & 23.9 & 14.6 & 1.8 & 0.5 & 100.0 \\
\hline & 50.0 & 31.8 & 15.0 & 18.0 & 31.6 & 2.2 & 1.4 & 100.0 \\
\hline & 80.0 & 29.8 & 13.0 & 16.9 & 38.3 & 2.0 & 0 & 100.0 \\
\hline & 100.0 & 22.0 & 8.9 & 12.9 & 54.8 & 1.4 & 0 & 100.0 \\
\hline
\end{tabular}

With an increase in the volumetric feed rate, the yield of light gas oil, in contrast to gasoline, not only does not decrease but increases significantly. When varying the concentration of air in the reaction mixture, a maximum concentration of the kerosene-gas oil fraction in the cracked products is also observed, corresponding to the air supply at a speed of $0.15 \mathrm{~h}^{-1}$. It was found that with an increase in the volumetric rate of suspension input by a factor of 10, the optimal air supply rate increases by 3 times. The study of the effect of temperature on the process (Table-5) showed that with its growth from 400 to $500^{\circ} \mathrm{C}$ the gas yield does not change, gasoline increases by $2 \mathrm{wt} . \%$, and the kerosene-gas oil fraction - by $9 \mathrm{wt} . \%$. With a further increase in temperature to $550^{\circ} \mathrm{C}$, the concentration of light hydrocarbons in the liquid fraction decreases, and the gas increases, which is associated with deeper destruction of hydrocarbon molecules at elevated temperatures. ${ }^{32-34}$ Thus, the optimum temperature is $500^{\circ} \mathrm{C}$.

To clarify the effect of cracking conditions on the mechanism of reactions occurring during its course, the hydrocarbon composition of the resulting gasoline fractions was determined by the chromatographic method (Table-6).

From Table-6 it follows that at low volumetric feed rates into the slurry reactor, the yield of diene and cyclodiene hydrocarbons in the presence of air additives increases significantly compared to cracking in an inert atmosphere. These data coincide with the literature ${ }^{35-37}$ that in the presence of air the proportion of the oxidative dehydrogenation of olefins increases. It is interesting that with an increase in the volumetric feed rate of the suspension, the direction of the oxidative cracking process changes. Unlike cracking at low space velocities, the concentration of olefin and diene hydrocarbons in gasoline obtained by the intensive supply of vacuum gas oil sharply decreases, while the concentration of aromatic hydrocarbons 
RASĀYAN J. Chem.

Vol. 13 | No. 4 |2370-2375| October - December | 2020

increases. This indicates that under these conditions, the oxidative dehydrogenation of olefins is suppressed and their cyclization to arenes begins. ${ }^{12,19,28}$ Confirmation of this is also an increase in the concentration of cycloolefins. The observed change in the reaction route can be explained by the following reasons. At a low feed rate, the cracked gas oil quickly reaches the temperature set in the reactor and is removed from it by evaporation. High temperature and short residence time determine the advantage of the oxidative dehydrogenation of hydrocarbons. With an increase in the volumetric rate of introducing the suspension, the duration of contact of the vacuum gas oil with the catalyst increases, since the cracked feed accumulates in the reactor in the form of a liquid phase mixed with a finely divided composite. The oxidative dehydrogenation of cycloparaffins and the condensation of olefins to aromatic hydrocarbons have time to proceed on the surface of the catalyst.

Table-6: Hydrocarbon Composition (\%) of Gasoline Cracking Vacuum Distillate of Atyrau Oil $\left(0.2\right.$ wt. $\%$ in raw material of $14 \%$ composite, $\left.\mathrm{T}=500^{\circ} \mathrm{C}\right)$

\begin{tabular}{c|c|c|c}
\hline Hydrocarbon Composition & $\begin{array}{c}\mathrm{W}_{\text {suspension }}=0.1 \mathrm{~h}^{-1}, \\
\text { Inert Atmosphere }\end{array}$ & $\begin{array}{c}\mathrm{W}_{\text {suspension }}=0.1 \mathrm{~h}^{-1}, \\
\mathrm{~W}_{\text {air }}=0.05 \mathrm{~h}^{-1}\end{array}$ & $\begin{array}{c}\mathrm{W}_{\text {suspension }}=1.0 \mathrm{~h}^{-1}, \\
\mathrm{~W}_{\text {air }}=0.15 \mathrm{~h}^{-1}\end{array}$ \\
\hline n-paraffins & 4.5 & 3.2 & 4.2 \\
\hline Isoparaffins & 18.8 & 27.1 & 29.7 \\
\hline Naphthenes & 12.8 & 10.0 & 9.2 \\
\hline Olefins & 20.2 & 18.0 & 4.6 \\
\hline Cycloolefins & 1.6 & 1.3 & 41.3 \\
\hline Arenes & 28.6 & 26.8 & 1.6 \\
\hline Dienes & 1.3 & 10.3 & 0.1 \\
\hline Cyclodienes & 0.2 & 0.7 & - \\
\hline Unidentified & 6.5 & 0.1 & 91.2 \\
\hline
\end{tabular}

\section{CONCLUSION}

The novelty of the presented work lies in the originality of the oxidative catalytic cracking process of vacuum distillates using composites based on natural zeolites of Kazakhstan. In this research vacuum distillates obtained by distillation under reduced pressure of the Zhetybay and Atyrau oils were subjected to catalytic cracking. Catalysts were prepared from natural Taizhuzgen zeolite and Narynkol clay. The results of a study on the use of activation of cracked oils by introducing air additives into the reaction zone indicate the great promise of a new direction in the catalytic processing of heavy hydrocarbon feedstocks.

\section{ACKNOWLEDGEMENT}

The work was carried out within the framework of program-targeted financing, under the program: No. BR 05236634 "Development of technology for obtaining new multifunctional porous magnetically controlled nanoscale materials based on fly ash cenospheres for immobilization, solidification and neutralization of radiation waste".

\section{REFERENCES}

1. P. O'Connor, Studies in Surface Science and Catalysis, 166, 227(2007), DOI:10.1016/s01672991(07)80198-4

2. R. Pujro, M. Falco and U. Sedran, Energy \& Fuels, 29(3), 1543(2015), DOI:10.1021/ef502707w

3. X. Liu, Fuel Processing Technology, 86(2), 151(2004), DOI:10.1016/s0378-3820(04)00049-9

4. T. Nambaya Charyulu, P. Naveenchandran, E. Raja and R. N. Babu, Rasayan Journal of Chemistry, 13(2), 876(2020), DOI: 10.31788/RJC.2020.1325560

5. C. Senter, M.C. Mastry, A.M. Mannion, R.Jr. McGuire, D. Houtz and B. Yilmaz, Catalysts, 9(10), 831(2019), DOI: 10.3390/catal9100831

6. T.V. Shakiyeva, L.R. Sassykova, U.N. Dzhatkambayeva, N.K. Zhakirova, M. Prabhahar, S. Sendilvelan, M. Ganesan, N. Jaya Chitra and R. Hari, Materials Today: Proceedings (2020), DOI: 10.1016/j.matpr.2020.09

7. S. Sendilvelan, L.R.Sassykova and M.Prabhahar, News of the National Academy of Sciences of the Republic of Kazakhstan, Series of Geology and Technical Sciences, 435(3), 6(2019), DOI:10.32014/2019.2518-170X.61 
RASĀYAN J. Chem.

Vol. 13 | No. 4 |2370-2375| October - December | 2020

8. B.T. Tuktin, A.S. Tenizbayeva, A.A. Omarova, L.R. Sassykova and Zh.A. Sailau, Rasayan Journal of Chemistry, 12(3), 1478(2019), DOI:10.31788/RJC.2019.1235236.

9. L.R. Sassykova, Chemical and Biochemical Engineering Quarterly, 31, 447(2017), DOI: $10.15255 /$ cabeq.2016.959

10. H. Topsoe, Applied Catalysis A: General, 322, 3(2007), DOI:10.1016/j.apcata.2007.01.002

11. J.N. Beltramini, Studies in Surface Science and Catalysis, 146, 653(2003), DOI:10.1016/s01672991(03)80468-8

12. C. Boyadjian and L. Lefferts, European Journal of Inorganic Chemistry, 2018(19), 1956(2018), DOI: 10.1002/ejic.201701280.

13. T.R. Brueva, I.V. Mishin and G.I. Kapustin, Thermochimica Acta, 379, 15(2001), DOI: 10.1016/s0040-6031(01)00597-4

14. S.W. Kim, C.E. Yeo and D.Y. Lee, Energies, 12(2), 293 (2019), DOI:10.3390/en12020293.

15. S. M. Rigutto, R. Veen and H. Laurent, Studies in Surface Science and Catalysis, 168, 855(2007), DOI: 10.1016/s0167-2991(07)80812-3

16. A. Omarova, L. Sassykova, M. Tulepov and N. Zhakirova, Journal of Chemical Technology and Metallurgy, 54(3), 547(2019)

17. X. Liu, W. Li, H. Zhu, Q. Ge, Y. Chen and H. Xu, Catalysis Letters, 94, 31(2004), DOI: $10.1023 / \mathrm{b}:$ catl.0000019327.86674.98.

18. I. E. Maxwell and W.H.J. Stork, Studies in Surface Science and Catalysis, 137, 747(2001), DOI: 10.1016/s0167-2991(01)80259-7

19. S. Fukase and F. Maruyama, Journal of The Japan Petroleum Institute, 37(6), 611(1994), DOI: $10.1627 /$ jpi1958.37.611

20. L. Sassykova, S. Sendilvelan, M. Telbayeva, K. Dossumov and K. Bhaskar, Journal of Chemical Technology and Metallurgy, 54(3), 539(2019)

21. J.H. Chen, J.N. Lin, Y. M. Kang, W.Y. Yu, C.N. Kuo and B.Z. Wan, Applied Catalysis A: General, 291(1-2), 162(2005), DOI:10.1016/j.apcata.2005.02.038

22. M. Stocker, Microporous and Mesoporous Materials, 82, 257(2005), DOI: 10.1016/j.micromeso.2005.01.039

23. V. Blay, E. Epelde, R. Miravalles and L. A. Perea, Catal. Rev. Sci. Eng., 60, 278(2018), DOI: $10.1080 / 01614940.2018 .1432017$

24. N. Viswanadham, G. Muralidhar and T.S.R. Prasada Rao, Journal of Molecular Catalysis A: Chemical, 223(1-2), 269(2004), DOI:10.1016/j.molcata.2003.11.045.

25. M. Lassinantti, J. Hedlund and J. Sterte, Micropores and Mesopores Materials, 38(1), 25(2000), DOI:10.1016/S1387-1811(99)00296-6.

26. M.A. Abul-Hamayel, Chemical Engineering \& Technology, 25(1), 65(2002)

27. S. Standl and O. Hinrichsen, Catalysts, 8(12), 626(2018), DOI:10.3390/catal8120626

28. F.N. Guerzoni and J. Abbot, Journal of Catalysis, 139(1), 289(1993), DOI:10.1006/jcat.1993.1024

29. T. Cheung, Journal of Catalysis, 124(2), 511(1990), DOI:10.1016/0021-9517(90)90197-r

30. D. Orlicki, U. Navarro, M. Ni and L. Langan, Chemical Industries, 173-198(2010)

31. L.R. Sassykova, N.K. Zhakirova, Y.A. Aubakirov, S. Sendilvelan, Z.K. Tashmukhambetova, T. S. Abildin, B. D. Balgysheva, A. A. Omarova, M. A. Sarybayev and L. K. Beisembaeva, Rasayan Journal of Chemistry, 13(3), 1444(2020), DOI:10.31788/ RJC.2020.1335822

32. Zh. Kh. Tashmukhambetova, N.K. Zhakirova, L.R. Sassykova, K. A. Kadirbekov, Y.A. Aubakirov and A.S. Zhumakanova, Oriental Journal of Chemistry, 33(6), 2803(2017)

33. Y. Wang and J. Wang, Petrochemical Technology, 6, 453(2003)

34. M.Y. He, Catalysis Today, 73(1-2), 49(2002), DOI:10.1016/s0920-5861(01)00517-x

35. T. Okuhara, Shokubai. Catalysts and Catalysis, 1, 32(2003)

36. Y. Ren, B. Yue, M. Gu and H. He, Materials, 3, 764(2010), DOI:10.3390/ma3020764

37. K. Wada, K. Tada, N. Itayama, T. Kondo and T. Mitsudo, Journal of Catalysis, 228(2), 374(2004), DOI: 10.1016/j.jcat.2004.09.009

[RJC-5948/2020] 